\title{
Norbert Slenzok
}

Uniwersytet Ślaski

\section{Dwa argumenty na rzecz libertarianizmu w teorii prawa naturalnego Murraya Rothbarda}

\section{Two arguments for libertarianism in Murray Rothbard's theory of natural law}

\author{
$22 / 2017$ \\ Political Dialogues \\ DOI: http://dx.doi.org/10.12775/DP.2017.002
}

\begin{abstract}
:
The purpose of the presented paper is the presentation and critical assesment of the two arguments for the principle of self-ownership raised by the founding father of libertarianism - an economist and political philosopher Murray Newton Rothbard (1926-1995). As author points out, both arguments are rooted in the theory of natural law and natural rights. He argues that this theory, in addition to being untenable per se, is incompatbile with the ethics of libertarianism and therefore every libertarian argument set on its stone must inevitably fail. However, according to the author, Rothbard's second argument - that is, the argumentum a contrario, is logically indipendent of the natural law theory and, thus, can be defended on different philosophical grounds, although Rothbard himself derived it from the erroneous natural law premises.
\end{abstract}

Słowa kluczowe: Murray Rothbard, libertarianizm, prawo naturalne, teoria prawa naturalnego, zasada samoposiadania
Keywords: Murray Rothbard, libertarianizm, natural law, theory of natural law, self-ownership principle

\section{Wstęp}

Przedmiotem niniejszego artykułu będa poglądy etyczne twórcy filozofii politycznej libertarianizmu - filozofa i ekonomisty Murraya Newtona Rothbarda (19261995) ${ }^{1}$. Jadro tej koncepcji stanowi - jak celnie wskazuje Dariusz Juruś - uznanie absolutnego statusu prawa własności. ${ }^{2}$ Jest ono na gruncie libertarianizmu eksplikowane w dwójnasób: jako prawo autowłasności (bądź, jak najczęściej tłumaczy się angielski termin self-ownership, samoposiadania) ${ }^{3}$ oraz prawo własności

${ }^{1}$ Nt. sylwetki Rothbarda zob. J. Raimondo, Przeciw państwu. Biografia Murraya N. Rothbarda, tłum. J. Wozinski, Warszawa 2016.

${ }^{2}$ D. Juruś, $W$ poszukiwaniu podstaw libertarianizmu. W perspektywie Rothbardowskiej koncepcji własności, Kraków 2012, s. 10.

${ }^{3}$ Ibidem, s. 78, przyp. 301.; Ł. Dominiak, Problem aksjomatyczności zasady autowłasności $w$ filozofii politycznej libertarianizmu, „Athenaeum. Polskie Studia Politologiczne" 49/2016, s. 42-61 Trzeba powtórzyć za Dominiakiem i Jurusiem, że $z$ analitycznego punktu widzenia użycie jednego bądź drugiego terminu nie jest obojętne i nie należy 
dotyczące materialnych przedmiotów zewnętrznych. W legitymowalne posiadanie tych ostatnich można zaś - jak wylicza uczeń Rothbarda Hans-Hermann Hoppe - wejść na trzy możliwe sposoby: a) poprzez pierwotne pierwotne zawłaszczenie wolnego przedtem zasobu; b) poprzez wyprodukowanie nieistniejącego wcześniej dobra; c) poprzez pozyskanie dobra w drodze dobrowolnego transferu. 4 Norma poszanowania tak definiowanego prawa własności nosi natomiast miano „aksjomatu nieagresji” bądź „zasady nieagresji" (ang. non-agression axiom, non agression principle). ${ }^{5}$

Swoja argumentację na rzecz libertariańskich pryncypiów rozwijał Rothbard w oparciu o synteze klasycznej, arystotelesowsko-tomistycznej tradycji prawa naturalnego $z$ nowożytna, wywodzaca się od Johna Locke'a koncepcja naturalnych uprawnien. W swoich licznych pismach zaprezentował - jak pokażemy - dwa logicznie niezależne argumenty, majace wspierać filozofię moralną libertarianizmu. W przedkładanym artykule stawiamy sobie za cel wykazanie prawdziwości następującej tezy. Otóż - twierdzimy - oba argumenty Rothbarda upadaja $z$ uwagi fakt, iż zakorzenione sa w filozofii prawa naturalnego, obarczonej $z$ jednej strony inherentnymi defektami, $z$ drugiej zaś - niekompatybilnej z liberalizmem i libertarianizmem. Sadzimy wszelako zarazem, że drugi $z$ argumentów Rothbarda, o strukturze dowodu a contrario, wykazuje większy potencjał

traktować ich synonimicznie. Posiadanie oznacza bowiem sprawowanie kontroli nad jakimś dobrem; tylko własność natomiast stanowi posiadanie prawomocne.

${ }^{4}$ H-H. Hoppe, Państwo czy społeczeństwo prawa prywatnego?, [w:] Krótka historia człowieka, thum. Ł. Dominiak, Warszawa 2014, s. 99.

${ }^{5}$ Zob. np. M.N. Rothbard, O nowa wolność. Manifest libertariański, tłum. W. Falkowski, Warszawa 2007, s. 45. i może być skutecznie broniony na niwie innej niż iusnaturalizm teorii etycznej.

By uniknać niejasności, podkreślmy, że w artykule rozpatrujemy wyłącznie problem zasady autowłasności, zostawiając na boku równie newralgiczna dla libertarian kwestię własności zasobów zewnętrznych. Czynimy to zarówno ze względu na objętość tekstu, jak i kierując się własnym poglądem, że to problem autowłasności ma dla libertarianizmu znaczenie prymarne. Jeśli bowiem każdy dysponuje prawem własności do siebie samego i jest to prawo absolutne, to nie widać, na podstawie jakich racji ograniczone miałoby zostać jego prawo do posługiwania się obiektami zewnętrznymi, jeśli tylko korzysta on $z$ nich bez naruszania prawa autowłasności innych osób.

Warto zaznaczyć, że niniejszy tekst podejmuje problematykę dotychczas w polskiej literaturze na temat libertarianizmu niezbadaną. W istniejaccych opracowaniach myśli Rothbarda rezygnuje się $z$ ewaluacji wartości logicznej prezentowanego przez niego iusnaturalistycznego uzasadnienia libertarianizmu, pozostajac przy czysto sprawozdawczym ujęciu zagadnienia. Czynia tak autorzy wszystkich trzech dostepnych polskich monografii dorobku Rothbarda: Dariusz Juruś, Radosław Wojtyszyn i Jakub Wozinski ${ }^{6}$, a także amerykański filozof związany $z$ alabamskim Mises Institute i kolega Rothbarda David Gordon w swoim popularnym wprowadzeniu do jego myśli. ${ }^{7}$ Niżej podpisany w swoim wcześniejszym artykule poświęconym etycznemu

${ }^{6}$ D. Juruś, W poszukiwaniu podstaw libertarianizmu, op. cit. R. Wojtyszyn, Anty-Lewiatan. Doktryna polityczna $i$ prawna Murraya Newtona Rothbarda, Wrocław 2017, s. 86 i nn., J. Wozinski, Antropologia libertarianizmu, Poznań 2016.

7 D. Gordon, The Essential Rothbard, Aurburn 2007, s. 87-94. 
stanowisku Rothbarda eksponował zaś co prawda pewne przewagi, jakie przysługuja zawartej w nim koncepcji wolności względem teorii alternatywnych, wszelako zaledwie sygnalizował możliwe trudności związane $z$ samym uzasadnieniem moralnej słuszności owej koncepcji. ${ }^{8} \mathrm{Z}$ kolei $\mathrm{w}$ literaturze anglojęzycznej obszernej krytyki wywodów twórcy „Etyki wolności" podjał się Edward Feser, ${ }^{9}$ spotykając się $z$ apologetyczną wobec Rothbarda replika Gerarda Caseya. ${ }^{10} \mathrm{Czę-}$ ściowo - o czym szerzej piszemy w dalszej części tekstu - zdystansował się natomiast od koncepcji swojego mistrza najważniejszy z jego uczniów Hans-Hermann Hoppe. Do prac wszystkich wspomnianych autorów będziemy się w toku rozważań obszernie odwoływać.

\section{Prawo i uprawnienia naturalne w ujęciu Rothbarda}

Nie sposób nie przychylić się do opinii Fesera, że Rothbard musiał przypisywać swoim argumentom wysoka wartość. ${ }^{11} \mathrm{~W}$ treściowo niemal niemodyfikowanej postaci ${ }^{12}$ prezentował je bowiem w co najmniej trzech różnych miejscach: ksiażkach „O nową wolność. Manifest

8 N. Slenzok. Idea wolności $w$ etyce społecznej Murraya N. Rothbarda, [w:] O. Sroczyński (red.), Wolność, moralność i efektywność. Wybrane problemy współczesnej etyki społecznej i gospodarczej, Katowice 2014.

9 E. Feser, Rothbard as a Philosopher, dostęp $z$ dn. 20.04.2017:http://edwardfeser.blogspot. com / 2009/08/rothbard-as-philosopher.html; idem, Rothbard Revisited, dostęp z dn. 20.04.2017: http: / / edwardfeser.blogspot.com/2009/08/rothbard-revisited.html.

10 G. Casey, Feser on Rothbard as a Philosopsher, „Libertarian Papers” 1/34 (2009).

11 E. Feser, op. cit.

12 O jedynej - niemniej istotnej - różnicy piszemy niżej. libertariański”, 13 „Etyka wolności”, 14 a także w artykule „Sprawiedliwość i prawa własności", przedrukowanym następnie w zbiorze esejów „Egalitaryzm jako bunt przeciwko ludzkiej naturze". ${ }^{15}$ Ponieważ najbardziej rozbudowany wywód zawiera „Etyka wolności”, argumentację Rothbarda będziemy cytować głównie za tym jego dziełem.

Oba argumenty, osobliwie zaś pierwszy z nich, zrozumieć można - jak już wzmiankowano - wyłacznie w ramach całości prawno-naturalnego stanowiska Rothbarda. Jak więc autor ten pojmuje prawo naturalne? Co dla tego rodzaju koncepcji typowe, metafizycznych i epistemologicznych fundamentów dostarcza tu realistyczna filozofia arystotelesowsko-tomistyczna.

Wyjściowym założeniem ontologicznym jest więc dla Rothbarda esencjalizm - przedmioty, tak jako jednostki, jak i jako egzemplarze gatunku, istnieją w sposób niezależny od świadomości, wyróżniając się spośród innych bytów określoną charakterystyką.

Jest rzeczą naprawdę niezrozumiałą, że tak wielu współczesnych filozofów prycha na sam termin „natura”, jakby im ktoś wstrzyknął trutkę mistycyzmu i czegoś ponadnaturalnego. Jabłko, gdy zwisa, spadnie kiedyś na ziemię; obserwujemy to wszyscy i uznajemy, że jest to w naturze jabłka (jak również świata w ogóle). Dwa atomy wodoru połączone $z$ jednym atomem tlenu dadzą cząstkę wody - zachowanie, które jest wyjątkowe dla natury wodoru, tlenu i wody. Nie ma w tych ob-

${ }^{13}$ M.N. Rothbard, O nowa wolność..., op. cit., s. $48 \mathrm{i} \mathrm{nn.}$

${ }^{14}$ Idem, Etyka wolności, tłum. J. Wozinski, Warszawa 2010, s. 127-134.

${ }^{15}$ Idem, Sprawiedliwość i prawa własności, [w:] Egalitaryzm jako bunt przeciwko ludzkiej naturze, tłum. K. Węgrzecki, Warszawa 2009, s.143 i nn. 
serwacjach nic tajemniczego ani mistycznego. Po co zatem spierać się o koncepcję „natury”? Świat składa się w rzeczywistości z niezliczonej ilości obserwowalnych rzeczy lub jednostek. Jest to z całą pewnością dający się zaobserwować fakt. Jako że świat nie składa się z jednej homogenicznej rzeczy lub jednej jednostki, wynika z tego, że każda z tych odmiennych rzeczy posiada różniące się atrybuty, w przeciwnym razie wszystkie byłby jedną $\mathrm{i}$ tą samą rzeczą. Ale jeśli A, B. C itd. mają różne cechy, to wynika $z$ tego bezpośrednio, że mają także różne natury - pisze Rothbard. ${ }^{16}$

Jak widać $z$ przytaczanego fragmentu, esencjalizm Rothbarda jest realizmem pojęciowym spod znaku Arystotelesa, nie Platona. Samodzielnie istnieja. tylko jednostki, indywidua. Gdzie indziej Rothbard dodaje: „Prawo naturalne zasadza się na kluczowym rozpoznaniu, że być z konieczności znaczy być czymś, czyli pewna szczególną rzeczą bądź istotą. Nie ma czegoś takiego jak abstrakcyjny Byt". ${ }^{17}$

Choć Rothbard nie pisze tego expressis verbis, nie rozwodzac się nad własnym poglądem w sporze o uniwersalia ${ }^{18}, \mathrm{w}$ indywiduach tkwia jednak również cechy ogólne, gatunkowe. $\mathrm{W}$ przeciwnym razie nauka o prawie naturalnym nie byłaby możliwa. W ogólności zresztą należy zauważyć, że Arystotelesowska koncepcja pojęć ogólnych najlepiej nadaje się do ugruntowania teorii prawa naturalnego $\mathrm{w}$ wersji indywidualistycznej. $Z$ jednej bowiem strony nie przypisuje ona - jak

${ }^{16}$ Idem, Etyka wolności, s. 82-83.

17 Idem, Economic Thought Before Adam Smith, Aurburn 1995, s. 3.

${ }^{18} \mathrm{O}$ niekonsekwentnych wypowiedziach Rohtbarda w tym zakresie pisze M.. Barczentewicz, Etyka wolności Murraya Rothbarda, [w:] M.N. Rothbard, Etyka wolności, s. 55-56. platonizm - ogółowi ontologicznego prymatu względem szczegółu, z drugiej inaczej niż nominalizm - uznaje realność gatunków, co stanowi warunek sine qua non dorzecznego mówienia o prawach wynikających $z$ samej przynależności gatunkowej - faktu bycia człowiekiem. ${ }^{19}$

Rzecz jasna, założeniem epistemologicznym etyki Rothbarda okazuje się racjonalizm. Prawo naturalne nie stanowi jak chciał Jeremy Bentham - „nonsensu na szczudłach" także dlatego, że rozum ludzki zdolny jest do uchwycenia obiektywnych praw rzadzacych rzeczywistościa - natur poszczególnych bytów. ${ }^{20} \mathrm{Co}$ istotne, mimo że autor „Etyki wolności” odwołuje się w swoich poglądach wprost do historycznych i współczesnych myślicieli chrześcijańskich: św. Tomasza z Akwinu, Franciszka Suareza, Hugo Grocjusza, a także Henry'ego Veatcha i Alvina Plantingi, wyraźnie eksponuje on świecki, tj. religijnie neutralny charakter nauki o prawie naturalnym. $Z$ aprobata cytuje m.in. fragment „De Iure Belli et Pacis" Grocjusza, w którym ten oznajmia, że jego doktryna zachowywałaby walor prawdy nawet jeśliby Bóg nie istniał; sam zaś Bóg, choć wszechmocny, nie jest w stanie unieważnić obiektywnych relacji między dobrem a złem. ${ }^{21}$ Podobny pogląd na relacje pomiędzy Bogiem a prawem naturalnym przypisuje Rothbard - przywołujacc wypowiedzi Suareza - nurtowi tomistycznemu. ${ }^{22}$

Innym - tym razem niewyartykułowanym explicite - założeniem etyki Rothbarda jest teleologiczna wizja świata. ${ }^{23}$

19 Nt. związków między filozofią Rothbarda a klasyczna filozofia arystotelesowska i tomistyczna por. szczególnie J. Wozinski, Antopologia libertarianizmu, op. cit., ibidem.

${ }^{20}$ M.N. Rothbard, Etyka wolności, op. cit., s. $76-82$.

${ }^{21}$ Ibidem, s. 78

22 Ibidem, s. 77 i nn

${ }^{23}$ W „Economic Thought Before Adam Smith” 
Wbrew zainaugurowanej przez Hume'a z jego sławną "gilotyną" nowożytnej i współczesnej tendencji do aksjologicznej neutralizacji bytu, twórca libertarianizmu utrzymuje, że badając byt, możemy zidentyfikować nie tylko obiektywne zależności (prawa w sensie opisowym), lecz także obiektywne powinności (prawa w sensie normatywnym). W świetle tej pochodzącej od Arystotelesa koncepcji, w naturze każdego bytu leży dążenie do właściwego mu celu, potencjalnie w nim zawartego, domagajacego się aktualizacji i stanowiącego specyficzne dlań dobro.

Leo Strauss wyjaśnia ten pogląd: „Określonej konstytucji odpowiada określone działanie, określona praca. Jakaś istota jest "W porzadku", jeśli dobrze spełnia właściwe sobie zadanie”. ${ }^{24}$ Tak oto uprawomocniona ma zostać - wedle wyrażenia Rothbarda - obiektywna nauka o ludzkim szczęściu. Rothbard przekonuje:

W przypadku człowieka etyka prawa naturalnego orzeka, że dobro lub zło może być ustalone w świetle tego, co wypełnia lub blokuje ludzką naturę. Prawo naturalne naświetla zatem, co jest dobre dla człowieka - do jakich celów powinien on dążyć i które zachowują harmonię z naturą ludzką oraz ją spełniają 25 .

Charakterystyczny dla reprezentowanej przez Rothbarda austriackiej szkoły ekonomii subiektywizm wartości zostaje zatem przezwyciężony na gruncie

Rothbard zawęża zakres denotacji terminu „celowość” do zachowań organizmów żywych, niemniej nie uzasadnia on tego rozstrzygnięcia. Nadto, stoi ono w sprzeczności $z$ wypowiedziami cytowanych przez Rothbarda filozofów prawa natury. M.N. Rothbard, Economic Thought Before Adam Smith, op. cit., s. 4.

${ }^{24}$ L. Strauss, Prawo naturalne $w$ swietle historii tłum. T. Górski, Warszawa 1969, s. 119.

25 M.N. Rothbard, Etyka wolności, s. 86. etyki i ograniczony do obszaru ekonomii. Autor „Etyki wolności” jednoznacznie zajmuje stanowisko klasycznego eudajmonizmu: indywidualne preferencje uchodza w jego oczach za moralnie irrelewantne, ponieważ w sferze moralności istnieje obiektywny porzadek, ufundowany na naturze ludzkiej i dyktujacy podmiotowi powszechnie wiążące kategorie dobra i zła. ${ }^{26} \mathrm{~W}$ ten sposób usiłuje też Rothbard uchylić Hume'owska dychotomię faktów i wartości: wartości (powinności) sa dla niego immanentnie zawarte w faktach (bycie) jako naturalne tendencje przedmiotów. Za parokroć przez siebie cytowanym Johnem Wildem amerykański myśliciel przyjmuje, że „Z samego opisu i analizy danej tendencji możemy wywnioskować zbudowana na niej wartość. Dlatego też nie mówimy, że zasady moralne sa zaledwie zdaniami o faktach, lecz raczej, że sa one "zbudowane" na faktach"27.

Mimo to dostrzega Rothbard antyindywidualistyczna orientację arystotelesowsko-tomistycznych doktryn prawna naturalnego. Zgodnie ze znanym ujęciem Straussa, w dziejach iusnaturalizmu wyodrębnić można dwie antagonistyczne linie. Uznawana za klasyczna linia Arystotelesa, Akwinaty i ich kontynuatorów jest jedna $z$ nich, zaś sedno jej stanowi pierwszeństwo naturalnych obowiazków przed naturalnymi uprawnieniami, wsparte na przekonaniu o istnieniu pozytywnych norm postepowania, wymaganych od człowieka przez jego własna naturę. Tymczasem druga linia, obejmujaca takich filozofów jak Grocjusz, Samuel Pufendorf, Thomas Hobbes, a przede wszystkim John Locke i szczególnie bliski Rothbardowi amerykański

${ }^{26}$ Ibidem, s. 86-87.

27 J. Wild, Natural Law and Modern Ethical Theory, „Ehics” 1952, t.63, nr 1, s. 11. cyt. Za: M.N. Rothbard. Etyka wolności, s. 88, przyp. 30. 
anarchoindywidalista Lysander Spooner, koncentruje się na ludzkich indywidualnych uprawnieniach, dokonując tym samym - jak sadzi Rothbard - niezbędnej korekty doktryn klasyków. ${ }^{28}$ Rację ma zatem Juruś, podsumowując pozycje Rothbarda w spektrum koncepcji iusnaturalistycznych następujaco: „Podkreślając wielokrotnie obiektywizm $i$ indywidualizm tej etyki, łaczy Rothbard klasyczna tradycję prawnonaturalna Z nowożytną". ${ }^{29}$

\section{Argument wprost}

Jak tedy przedstawia się argumentacja Rothbarda na rzecz etycznych pryncypiów libertarianizmu? Powyższa specyfikacja Rothbardowskiego ujęcia prawa naturalnego pozwala naświetlić w szczególności tło pierwszego $z$ dwu argumentów. Przebiega on, wedle sformułowania Rothbarda, jak następuje:

(...) Zachowanie roślin i przynajmniej niższych zwierząt określone jest przez ich naturę biologiczną lub przez ich „instynkty", gdy tymczasem natura ludzka decyduje o tym, że człowiek, chcąc działać, musi sam stawiać sobie cele i dobierać metody ich osiągnięcia. Nie posiadając automatycznych instynktów, każdy musi poznać siebie i otaczający świat, świadomie wybierać wartości, zrozumieć związek między przyczyną i skutkiem; żeby utrzymać się przy życiu i rozwijać się, musi działać z nastawieniem na cel. Ponieważ ludzie mogą myśleć, czuć i oceniać tylko jako jednostki, to każdy musi mieć zagwarantowaną wolność poznawania, wybierania, rozwijania zdolności i działania

28 L. Strauss, Prawo naturalne..., op. cit., s. 227-228. M.N. Rothbard, op. cit, s. 97.

29 D. Juruś, W poszukiwaniu podstaw libertarianizmu, op. cit., s. 109. według posiadanej wiedzy i wyznawanych wartości. ${ }^{30}$

To jednak nie wszystko. Będac profesjonalnym ekonomista, Rothbard również jako filozof uwrażliwiony jest na doniosłość faktu niedostatku - rzadkości dóbr ekonomicznych względem ludzkich potrzeb. Ponieważ człowiek nie jest bezcielesnym duchem, lecz bytem psychofizycznym posiadającym ciało i uzależnionym od zewnętrznych cielesnych przedmiotów, dla swojego przetrwania i rozwoju musi on gospodarować: poprzez swoja pracę przekształcać nature (w terminologii ekonomicznej: ziemię) w dobra kapitałowe. Jego indywidualna autonomia oznacza $\mathrm{w}$ tak funkcjonujacym świecie autonomię właściciela: swobodnie rozporzadzajacego dobrami, jakie nabył bez naruszenia odpowiednich praw innych, a nade wszystko - własnym ciałem, także mogacym być postrzegane jako dobro ekonomiczne. ${ }^{31}$

Czy argument ten można uznać za przekonywajacy? Nie wydaje się, i to z co najmniej kilku powodów. Po pierwsze, należy stwierdzić, że wywód autora „Manifestu libertariańskiego” obarczony jest ewidentnym błędem non sequitur. Z przesłanki głoszącej, że aby przetrwać i prosperować, działający aktor potrzebuje cieszyć się własnością, nie wynika s. 51.

${ }^{30}$ M.N. Rothbard, O nowa wolność..., op. cit.,

${ }^{31}$ Idem, Etyka wolności, op. cit., s. 107 i nn. Nadmieńmy, że sam Rothbard nie zawęża otwartym tekstem kategorii auto-własności do własności ciała, pisząc raczej o własności osoby. Precyzacji auto-własności jako odnoszącej się wyłącznie do ciała dokonuje Hans-Hermann Hoppe. Ma on słuszność o tyle, że osoba pojęta jako psychofizyczna całość nie może stanowić dobra rzadkiego w rozumieniu ekonomicznym (tylko byty fizyczne moga nimi być), a zatem także przedmiotu własności. Zob. np. H-H. Hoppe, Etyka i ekonomia własności prywatnej, [w:] Wielka fikcja, państwo w epoce schyłku, tłum. K. Nowacki, Warszawa 2014, s. 25. 
bowiem bynajmniej, iżby status tego prawa miał być absolutny. Ktoś - chociażby zwolennik katolickiej nauki społecznej mógłby z powodzeniem wywodzić, że jeśli teleologiczna racja prawa własności jest przetrwanie i rozwój człowieka, to konsekwentnie należy zawieszać je wówczas, gdy jego respektowanie wchodziłoby $z$ tymi celami w kolizję. ${ }^{32}$ Jak utrzymuje katolicka nauka moralna, nie popełnia grzechu ten, kto przymuszony śmiertelnym głodem dopuszcza się kradzieży. Tymczasem Rothbard - a w ślad za nim jego libertariańscy uczniowie i sukcesorzy - stojacc na stanowisku absolutyzmu prawa własności, domagaja się jego poszanowania nawet w sytuacjach zagrożenia życia ${ }^{33}$.

Co więcej, jak zauważa w swoim krytycznym komentarzu do etyki Rothbarda Edward Feser, polemista występujący $z$ pozycji egalitarystycznych mógłby łatwo odwrócić rozumowanie Rothbarda, korzystając $z$ niego do obrony którejś $z$ redystrybucjonistycznych wizji sprawiedliwości rozdzielczej. Feser punktuje: „Lewicowiec mógłby argumentować, że poszanowanie prawa auto-własności przyniosłoby korzyść tylko niektórym, wielu innych pozostawiajac ubogimi i ogołoconymi $z$ wszelkich interesujacych środków i celów, spośród których mieliby wybierać". ${ }^{34}$

Dalszy problem wiąże się ze wzmiankowanym już teleologicznym charakterem etyki Rothbarda, w której prawa własności pełnią rolę służebną wobec ludzkiego przetrwania i doskonalenia (flourishing). Rozważania myśliciela zawarte w „Etyce wolności” dodatkowo umacniaja prymat - mających, rzecz ja-

32 E. Feser, Rothbard as a Philosopher, op. cit.

${ }_{33}$ Por. Rothbarda analize sytuacji tzw. łodzi ratunkowej: M.N. Rothbard, Etyka wolności, op. cit., s. 254-260.

${ }^{34}$ E. Feser, Rothbard as a Philosopher, op. cit. sna, wynikać z człowieczej natury - celów nad prawami. Rothbard, podążając tropem innej wielkiej orędowniczki leseferyzmu Ayn Rand, ${ }^{35}$ usiłuje mianowicie dowieść, że afirmacja życia stanowi obiektywne, a wręcz niepodważalne dobro moralne. Utrzymuje on, że wartości życia niepodobna zaprzeczyć, ponieważ sam akt argumentacji na rzecz pogladu przeciwstawnego pociagałby za soba przyznanie życiu wartości - argumentować moga bowiem tylko żywi. ${ }^{36}$ Działania autodestrukcyjne, wymierzone przeciwko własnemu życiu i zdrowiu zostaja więc przez Rothbarda zakwalifikowane jako „obiektywnie niemoralne”. Człowiek, pisze Rothbard, „powinien opowiadać się za życiem (w sensie jego długości i jakości)". ${ }^{37}$

Rozumowanie to upada wskutek łatwo uchwytnego błędu logicznego - stąd, że w danej chwili żyje się i argumentuje, wynika jedynie, że afirmuje się własne życie na czas argumentacji, $z$ pewnościa jednak nie płynie $z$ tej przesłanki wniosek, że argumentujący uznaje wartość życie w ogóle - wszystkich ludzi i bez ograniczeń czasowo-funkcjonalnych. Pomińmy wszelako tę kwestię i przyjrzyjmy się, jakie sa implikacje Rothbardowskiego witalizmu dla libertariańskiej etyki wolności.

Ryszard Legutko w swoim „Traktacie o wolności" przeprowadza wiarygodna refutacje wszelkich odmian liberalizmu osadzonych w teorii prawa natury. Każda tego rodzaju teoria - koncepcja Rothbarda, w świetle jego własnych sformułowań, nie stanowi tu wyjątku - z konieczności odwoływać się musi do, jak powiada Legutko, „mocnej” wizji natury ludzkiej. Ta zaś obejmuje zarówno wizję

${ }^{35}$ Zob. A. Rand, Cnota egoizmu: nowa koncepcja egoizmu, tłum. J. Łoziński, Poznań 2000.

${ }^{36}$ M.N. Rothbard, op. cit., s. 111-112.

37 Ibidem, s. 111. 
naturalnych celów dyktowanych człowiekowi przez jego nature, jak i przekonanie o ich hierarchicznym uporzadkowaniu. Na terenie filozofii liberalnej rodzi się więc potencjalnie konflikt zasad, $z$ których jedna moglibyśmy określić jako zasadę wolności, a druga - zasada doskonałości. W przypadku gdy wolność zostanie wykorzystana przez jednostkę w sposób sprzeczny $z$ naturalnym telos, liberalizm utraci swoje antropologiczne umocowanie. Jeżeli wolność służyć ma wartościom definiowanym w ramach mocnej koncepcji człowieczeństwa, to najwyraźniej nic nie stoi na przeszkodzie, by ograniczyć ja tam, gdzie źle spełnia ona przewidziane jej instrumentalne zadania - wesprzeć przymusem wartości i zdelegalizować antywartości. ${ }^{38}$

Rothbard lub jego zwolennik mógłby bronić się przed taką krytyka, przyjmując w etyce indywidualnej stanowisko subiektywistyczne (relatywistyczne), limitowane wszakże uznaniem bezwzględnej wartości życia ludzkiego (przetrwania) i wynikającym zeń zakazem samobójstwa. W tym ujęciu jego rozumienie doskonalenia (flourishing) przypominałoby ideał moralnego powołania człowieka u Fichtego - każdy czyn byłby dobry, byleby mógł uchodzić za autonomiczny. Cała natomiast filozofia moralna Rothbarda okazywałaby się syntezą absolutyzmu prawa własności w etyce społecznej $z$ umiarkowanym (przez wzgląd na obiektywny nakaz zachowania życia) relatywizmem w etyce indywidualnej.

Nie sadzimy, by obrona taka mogła być skuteczna. Primo, kolidowałaby ona $z$ wielokroć eksponowanym przez Rothbarda rozróżnieniem pomiędzy tą częścia etyki, która dostarcza podstaw dla prawa pisanego i która jako filozof polityczny

${ }^{38}$ R. Legutko, Traktat o wolności, Gdańsk 2007, s. 47-51. zajmuje się Rothbard, a innymi sferami etyki, które nie musza bynajmniej być rozpatrywane jako domeny relatywizmu. To na przykład, że libertarianie optuja za mieszcząca się $\mathrm{w}$ absolutnym prawie własności swoboda działania dla pornografów bądź producentów i konsumentów narkotyków, nie ma wcale oznaczać, że udzielaja oni ich praktykom etycznej aprobaty. ${ }^{39}$ Najprawdopodobniej więc do tej linii obrony nie przychyliłby się sam Rothbard. Secundo, w zgodzie $z$ argumentami Legutki, obiektywny obowiazek afirmacji życia „w sensie jego długości i jakości" skutkuje nie tylko obecnym już w myśli Locke'a zakazem samobójstwa. Wymieńmy dla przykładu tylko kilka spośród etatystycznych polityk, wobec których libertarianin uznający nakaz dbałości o życie i zdrowie za prawo naturalne stawałby bezbronny: penalizacja handlu narkotykami i używania ich, zakazy palenia wyrobów tytoniowych tak w sferze publicznej, jak i lokalach prywatnych, restrykcyjna dystrybucja licencji na sprzedaż alkoholu ukierunkowana na redukcję jego spożycia, przymusowe szczepienia, specjalne podatki od niezdrowej żywności.

$\mathrm{Na}$ ostatek warto odwołać się do krytyki liberalizmu (ipso facto: libertarianizmu) prawnonaturalnego rozwijanej przez orędowników pluralizmu wartości - Isaiaha Berlina i jego krytycznego kontynuatora Johna Graya. Berlin i Gray przekonywająco wykazuja, że autentyczne, widziane $z$ perspektywy empirycznej, nie zaś z żadnego racjonalistycznego "wyższego punktu widzenia” życie moralne cechuje się nieprzezwyciężalnymi konfliktami wartości. Jednostki, kultury, a także cała ludzkość wytwarzają szerokie spektrum dóbr, celów i form życia,

${ }^{39}$ Zob. np. M.N. Rothbard, O nowa wolność..., op, cit., s. 140-142. 
z których bardzo wiele może być równie godnych wyboru ${ }^{40}$. Jak stwierdza Gray: „Jeżeli ktokolwiek $z$ nas zapyta: Jakiego życia wymaga ode mnie moja natura? jego pytanie pozostanie bez odpowiedzi”. 41 Wolność zaś, wbrew liberałom, nie stanowi niejako meta-wartości, neutralnych ram umożliwiających jednostkom swobodny wybór spośród dostępnych celów oraz środków działania i mieszczących w sobie je wszystkie. Ona również sytuuje się w szerokim spektrum odpowiadajacych udanemu życiu alternatyw. Najbardziej znana $z$ nich jest antagonizm między wolnością a niemożliwymi do pogodzenia $z$ nią rodzajami bezpieczeństwa, choćby bezpieczeństwem socjalnym. Nie dość jednak na tym. Należy podkreślić za Grayem, że szereg historycznych form życia, o których niepodobna orzec, iż sa w jakimkolwiek akceptowalnym sensie tego słowa „nienaturalne”, jest zwyczajnie niekompatybilnych $z$ liberalnym albo libertariańskim ładem społecznym. „Cnoty dworzanina, wojownika czy pobożnego włościanina możliwe sa jedynie na gruncie porzadku społecznego, który ze społeczeństwem liberalnym nie może koegzystować"42.

\section{Argument a contrario}

Przejdźmy teraz do drugiego $z$ argumentów Rothbarda, majacego strukturę dowodu nie wprost. Filozof zapytuje: jakie byłyby konsekwencje odmówienia jednostce prawa auto-własności? Możliwe sa jego zdaniem dwa warianty konkurencyjne:

40 Zob. I. Berlin, O dążeniu do ideału, [w:] Pokrzywione drzewo człowieczeństwa, tłum. M. Tański, Warszawa 2004, s. 1-17.. G. Gray, Dwie twarze liberalizmu, tłum. P. Rymarczyk, Warszawa 2001.

41 J. Gray, Postscriptum, [w:] Po liberalizmie. Eseje wybrane, tłum. P. Maciejko i P. Rymarczyk, Warszawa 2001, s. 37-38.

42 Ibidem, s. 42.
(...) Jeśli żaden człowiek nie ma prawa do pełnego i stuprocentowego samoposiadania, oto mamy do czynienia $z$ jednym z dwóch modeli: (1) Modelem „komunistycznym”, Powszechnego i Równego Cudzoposiadania, albo (2) Częściowego Posiadania Jednej Grupy przez Drugą, a więc $z$ systemem rządów jednej klasy nad drugą. Sa to jedyne logiczne alternatywy dla stuprocentowego samoposiadania przez wszystkich ludzi ${ }^{43}$.

Czy lista możliwości rozpatrywanych przez Rothbarda jest wyczerpujacca? W „Etyce wolności” zajmuje się on jeszcze jednym wariantem, zasugerowanym przez George'a Mavrodesa: „(...) Nikt nikogo nie posiada (na własność - przyp. N.S.), ani samego siebie, ani żadnego udziału w innej osobie". Rothbard odpowiada na to: „Jednakże, jako że posiadanie oznacza zakres kontroli, oznaczałoby to, że nikt nie byłby w stanie zrobić niczego. W takiej sytuacji ludzka rasa szybko by zniknęła"44. O perspektywie wyginięcia ludzkości jako ultima ratio argumentacji prawnonaturalnej u Rothbarda będzie jeszcze mowa. Tymczasem zajmijmy się krytyką Rothbardowskiego rozwiazania tej alternatywy przeprowadzona przez Fesera. Amerykański filozof oskarża Rothbarda o popełnienie błędu odwrócenia implikacji - z prawa własności do jakiegoś zasobu istotnie wynika prawo do kontroli nad nim, wszelako ze sprawowania kontroli nad dobrem nie wynika, iżby było się jego właścicielem. Aby przeżyć, potrzeba jedynie sprawować kontrolę nad własnym ciałem i innymi zasobami, bez konieczności bycia ich właścicielem ${ }^{45}$.

${ }^{43}$ M.N. Rothbard, Etyka wolności, op. cit., s. 127

44 Ibidem, przyp. 17.

45 E. Feser, Rothbard as a Philosopher, op. cit. 
W ogólności Feser ma bez watpienia słuszność co do asymetryczności relacji między własnościa a posiadaniem i gdyby Rothbard naprawdę przeoczył tę kwestię, to potwierdzałoby to opinię Fesera o jego lichych kompetencjach filozoficznych. Błą jednakże nie zachodzi, dopóki dyskusja odbywa się na terenie teorii prawa naturalnego (bądź jakiejkolwiek innej teorii uprawnień podmiotowych), która zresztą Feser - będąc neotomista - dzieli z Rothbardem. Na jej gruncie pytamy wszak o prawa, nie o fakty. Dla iusnaturalisty działania moga być albo wymagane, albo dopuszczane, albo zakazane przez prawo naturalne. Nie ma działań etycznie obojętnych. Pytanie o kontrolę zasobów staje się zatem $\mathrm{w}$ tej perspektywie pytaniem o prawo do kontroli, czyli - o prawo własności. Tym samym wariant Mavrodesa nie oznacza, że nikt fizycznie nie może niczego zrobić, ale że nikt nie ma do tego prawa.

Feser sądzi też, że prócz propozycji Mavrodesa, Rothbard powinien rozważyć jeszcze co najmniej kilka alternatyw: „b) Bóg posiada nas wszystkich; c) jedna klasa ludzi posiada jedynie częściowe prawo własności do innej klasy (...) d) każdy posiada częściowe i/lub nierówne prawo własności do wszystkich pozostałych"46. Wariant b) rozpatrujemy nieco dalej ${ }^{47}$. Co zaś się tyczy dwu pozostałych opcji, to należy zgodzić się z Caseyem i Gordonem, że $z$ punktu widzenia etycznych obiekcji, jakie można przeciwko nim skierować, nie różnią się one od wariantów omówionych przez Rothbar$\mathrm{da}^{48}$. Odnośnie do c) wypada ponadto zauważyć, że w przytaczanym przez nas wyimku z „Etyki wolności” Rothbard pisze właśnie o częściowym posiadaniu (na

46 Ibidem..

47 Patrz przyp. 74.

48 D. Gordon. The Essential Rothbard, op. cit., s. 90; G.Casey, Feser on Rothbard..., op. cit., s. 9. własność) jednej klasy przez druga Z kolei w cytowanym w tekście Fesera fragmencie "O nowa wolność" pojawia się zupełna, nie częściowa własność jednych w stosunku do drugich ${ }^{49}$. Nawet jeśli zamienne wymienianie tych możliwości świadczy o pewnej niefrasobliwości analitycznej Rothbarda, to pokazuje też, że uznawał je on za etycznie równoważne.

Przejdźmy teraz do alternatyw podanych przez Rothbarda i tak jak on zacznijmy od wariantu drugiego. Dlaczego, zdaniem autora „Etyki wolności”, jest on nie do utrzymania? Otóż narusza on kardynalna zasadę etyki prawa naturalnego, jaka jest tworzenie prawa moralnego "dla istot ludzkich jako takich". ${ }^{50}$ Innymi słowy, przyjęcie drugiej alternatywy dla prawa autowłasności oznaczałoby wyodrębnienie dwóch klas, niejako nadludzi i podludzi, do których odnosiłyby się odmienne normy etyczne. To zaś - argumentuje Rothbard - stoi w sprzeczności $z$ istota prawa naturalnego, zawierajacego system normatywny odnoszacy się do ludzi jako ludzi - przedstawicieli tego samego gatunku.

Podkreślić trzeba, że takie postawienie sprawy stanowi jądro argumentacji libertariańskiej w ogóle. Jak w innym miejscu powiada Rothbard:

Libertarianina można poznać po tym, że z żelazną konsekwencją i bezkompromisowo będzie stosował powszechne prawo moralne (wyróżnienie N.S.) do osób pracujących w aparacie państwa. Libertarianie nie znają tu wyjątków. Państwo (a ściślej mówiąc, „członkowie rządu”) przez całe wieki ubierało swoją przestępczą działalność w piękne słowa. Od wieków inicjowało masowe mordy, nazywało je „wojną” s. 52 .

49 M.N. Rothbard, O nowa wolność, op. cit.,

${ }^{50}$ Idem, Etyka wolności, op. cit, s. 128. 
i nobilitowało w ten sposób wzajemne wyrzynanie się tysięcy ludzi. Od wieków brało ludzi w niewolę, wcielając ich do sił zbrojnych i nazywając ten proceder „poborem” do zaszczytnej „służby dla kraju”. Od wieków dokonywało rabunku pod groźbą użycia broni, nazywając to „ściąganiem podatków”. Jeśli chcielibyście wiedzieć, jak wygląda państwo i jego postępki w oczach libertarianina, wystarczy, że wyobrazicie sobie państwo jako bandę kryminalistów. Cała libertariańska argumentacja staje się wtedy oczywista. ${ }^{51}$

Można więc powiedzieć, że sedno libertariańskiej etyki wyraża się w usunięciu powszechnie przyjętego dualizmu ocen moralnych, jakim poddaje się działalność osób prywatnych i państw. ${ }^{52}$

Jeśli zaś chodzi o pierwszą $z$ alternatyw, to także i ona musi upaśc, tym razem ze względów prakseologicznych. Etyka ufundowana na niej przechodzi wprawdzie pomyślnie tzw. test uniwersalizacji (stosuje się w identyczny sposób do wszystkich przedstawicieli gatunku ludzkiego), jej zastosowanie przyniosłoby wszelako ludzkości niechybna zagładę. Implikuje ona bowiem, że każdemu z ludzi przysługuje równa cząstka własności ciał wszystkich pozostałych. Jeśli, mówi Rothbard, „społeczeństwo liczy więcej niż pare osób", to nie mogac uczynić niczego bez zezwolenia całej reszty populacji, każdy wkrótce padłby trupem, a rasa ludzka wyginęłaby. Jedyna metoda powstrzymania tego procesu - skądinąd znana doskonale $z$ praktyki funkcjonowania historycznych państw komunistycznych - stałoby się przekazanie prawa do podejmowania decyzji w imieniu

51 Idem, O nowa wolność, op. cit., s. 72-73.

52 Szerzej na ten temat zob. M. Huemer, The Problem of Political Authority. An Examination of The Right to Coerse and the Duty to Obey, Basingtoke 2013. całości społeczeństwa wyspecjalizowanej klasie rządzacych, co jednak zwraca nas ponownie ku alternatywie (2), uprzednio już odrzuconej. ${ }^{53}$ Ponadto, jak dodaje Rothbard, nawet jeśliby utopia „powszechnego cudzoposiadania” dawała się urzeczywistnić, to i tak „jest absurdem twierdzić, że żaden człowiek nie ma prawa do posiadania siebie, i równocześnie uważać, że każdy z ludzi ma prawo posiadać część wszystkich pozostałych!"54.

Również Rothbardowski dowód a contario okazuje się jednak nieprzekonywajacy. Pierwszą silną obiekcję można skierować przeciwko sposobowi, w jaki rozprawia się Rothbard $z$ wariantem posiadania jednej klasy ludzi na własność przez druga. W „Manifeście libertariańskim" Rothbard stwierdza wręcz, że przyjęcie tej możliwości implikowałoby uznanie, że „klasa A ma prawa przynależne człowiekowi, podczas gdy klasa B to $\mathrm{w}$ istocie podludzie, którzy na takie prawa nie zasługuja”. ${ }^{55}$ Trzeba zgodzić się z Feserem, że wynikanie takie nie zachodzi. ${ }^{56}$ Co więcej, na jego krytykę musiałby w tym punkcie przystać sam Rothbard, biorac na poważnie własne enuncjacje odnośnie do egalitaryzmu, który nazywał on - w tytule jednego ze swych esejów - „buntem przeciwko ludzkiej naturze". ${ }^{57}$ Skoro ludzie $z$ natury sa nierówni, to co stoi na przeszkodzie, by stojac na gruncie etyki prawa naturalnego - nie tylko zaakceptować dysproporcje majątkowe między nimi, lecz także przypisać im nierówne prawa podmiotowe? $\mathrm{W}$ istocie, istotnym watkiem konserwatywnej argumentacji wymierzonej w li-

${ }^{53}$ M.N. Rothbard, Etyka wolności, op. cit., s. $128-129$.

54 Ibidem, s. 129.

55 Idem, O nowa wolność, op. cit., s. 52.

56 E. Feser, Rothbard as a Philosopher, op. cit.

57 M.N. Rothbard, Egalitaryzm jako bunt przeciw naturze, [w:] Egalitaryzm jako bunt przeciw naturze, op. cit., s. 29-54. 
beralną ideę równości wobec prawa było przekonanie, że jest ona niekompatybilna $z$ natura człowieka. W niej bowiem - wywodzili de Maistre, de Bonald i ich następcy - leży inherentna nierówność, która winna znajdywać odzwierciedlenie we wszystkich instytucjach społecznych $z$ prawem włącznie. ${ }^{58}$ Także Arystoteles i św. Tomasz - odpowiednio prekursor i ojciec bliskiej Rothbardowi tradycji myślenia o prawie naturalnym - niewątpliwie nie byli egalitarystami. Pierwszy jako $\mathrm{w}$ pełni naturalna postrzegał instytucję niewolnictwa, drugi - uznawał bez zastrzeżeń prawomocność ładu feudalnego.

Znacznie lepiej przedstawia się sprawa w przypadku Rothbardowskiej refutacji „modelu komunistycznego”. Rozpocznijmy wszelako od rozpoznania błędnych racji podnoszonych przez twórcę libertarianizmu przeciw „Powszechnemu i Równemu Cudzoposiadaniu". Konsekwencja przyjęcia go byłoby, powiada Rothbard, wymarcie rasy ludzkiej. Wolno zapytać: i co w tym złego? Wartość ludzkiego życia nie jest bynajmniej kwestia nieproblematyczna - jak wiadomo, Albert Camus w pytaniu o to, czy życie warte jest trudu, by je przeżyć, upatrywał prymarnego zagadnienia filozofii. ${ }^{59}$ Rothbard próbuje w swoich rozważaniach wynieść obowiazek zachowania życia do rangi aksjomatu, jednakże jego wysiłki - jak widzieliśmy - spełzaja na niczym. Można by nawet - korzystając $z$ cenionego przez Rothbarda dyskursu natury ludzkiej argumentować, że ponieważ w naturze człowieka leży świadomy stosunek do wartości, nie zaś bezrefleksyjne uleganie instynktowi samozachowania, ${ }^{60}$ może on

58 A. Wielomski, Konserwatyzm. Główne nurty, idee i postacie, Warszawa 2006, passim.

59 A. Camus, Mit Syzyfa, [w:] Dwa eseje, tłum. J. Guze, Warszawa 1991, s. 11.

60 Sam Rothbard w przytaczanym wcześniej ustępie przekonuje przecież: „Nie posiadając auto- w określonych warunkach uznać życie za niewarte przeżycia, decydując się na samobójstwo. Henryk Elzenberg pisal dobitnie:

Samobójstwo jest tą ostatnią rezerwą, tą ostatnią linią obronną, stanowiąca dla nas rękojmię, że poniżej pewnego poziomu poniżenia, upokorzenia, rozbicia wewnętrznego itp. nic i nikt nas zepchnąc nie może. Świadomość, że zawsze można popełnić samobójstwo, to nasze kryte tyły w walce życiowej. Zupełnie inaczej można się wtedy ustosunkować do każdej sprawy; życie nie tylko jest spokojniejsze, ale i o wiele piękniejsze. ${ }^{61}$

Co wolno stwierdzić o jednostce, stosuje się w tej kwestii równie dobrze do całej ludzkości. Nie jest niemożliwe („nienaturalne”), by wszyscy ludzie na ziemi zwatpili w sens dalszej egzystencji. W ogólności nie istnieja - wbrew Rothbardowi, ale też Akwinacie ${ }^{62}$ - żadne prawnonaturalne racje nakazujące widzieć w zniknięciu rasy ludzkiej moralnie niedopuszczalny obrót wydarzeń. Popełnić samobójstwo to oczywiście nie to samo, co zostać pozbawionym możliwości przeżycia i być może należy umożliwić ludzkości przetrwanie, ale stanowisko to (które skądinąd podzielamy) trzeba udowodnić, opierajac się na teorii praw (wykazując prawo ludzi do podjęcia działań ukierunkowanych na pozostanie przy życiu), nie zaś założyć w charakterze przesłanki teorii praw.

matycznych instynktów, każdy musi poznać siebie i otaczający świat, świadomie wybierać wartości (...)".

${ }^{61} \mathrm{H}$. Elzenberg, Klopot $\mathrm{z}$ istnieniem: aforyzmy w porzadku czasu, Torun 2002, s. 196.

${ }^{62}$ Tomasz łączył zakaz samobójstwa i zabójstwa oraz nakaz dbałości o życie i zdrowie $z$ naturalna skłonnością do samozachowania. R. Tokarczyk, Klasycy praw natury, Lublin 1988, s. 127-134. 
Powyższe zarzuty można wszakże utrącić (zaskakujące, że umknęło to Rothbardowi), sięgajac po pochodzacca od Misesa i Maxa Webera a przejęta przez Rothbarda definicję działania. Weber pisze: „Działanie oznacza ludzkie zachowanie (zewnętrzny lub wewnętrzny czyn, zaniechanie czy znoszenie- podkreślenie nasze - N.S.), jeśli i o ile działający, bądź wielu działających, wiąże $z$ tym zachowaniem pewien subiektywny sens". ${ }^{63}$ Sam zaś Rothbard wtóruje mu: „Należy podkreślić, że człowiek zawsze musi działać. (...) Nawet "nicnierobienie» jest forma działania". ${ }^{64}$ Właczajacc w zakres pojęcia działania także to, co wewnętrzne lub będące zaniechaniem, można zdyskredytować „model komunistyczny”, wskazujac, że wymaga on nie tylko śmierci ludzkości, ale po prostu niemożliwego - zaprzestania przez ludzi działania.

To jednak nasza wskazówka, natomiast wywód Rothbarda na temat „modelu komunistycznego" obarczony jest jeszcze jedna usterka, umykajaca notabene nie tylko jego stronnikom, ale również wysoce krytycznemu względem filozoficznego warsztatu autora „Etyki wolności” Feserowi. ${ }^{65}$ Otóż używając okresu warunkowego: „jeśli społeczeństwo liczy więcej niż parę osób, to alternatywa taka musi upaść". ${ }^{66}$ Rothbard sam wkłada

63 M. Weber, Gospodarka i społeczeństwo. Zarys socjologii rozumiejacej, tłum. tłum. D. Lachowska, Warszawa 2002, s. 6. Nt. Misesa koncepcji działania zob. L. von Mises, Ludzkie działanie. Traktat o ekonomii, tłum. W. Falkowski, Warszawa 2011, s. 9-11; idem, Epistemological Problems of Economics, Aurburn 2003, s. 24-28.

${ }^{64}$ M. N. Rothbard, Ekonomia wolnego rynku, t. 1, tlum. R. Rudowski, Warszawa 2007, s. 194.

65 Feser deklaruje, że właściwym celem jego artykułów o filozoficznych dokonaniach Rothbarda nie jest odparcie jego libertariańskich konkluzji, lecz obnażenie nieporadności, $z$ jaka argumentuje on na ich rzecz.E. Feser, Rothbard as a Philosopher, op. cit. s. 129 . kontrargument $\mathrm{w}$ ręce swoich oponentów. Co mianowicie jeżeli społeczeństwo nie liczy więcej niż parę osób? Wyobraźmy sobie, że nastąpiła zagłada nuklearna, która przetrwało zaledwie kilku ludzi ukrytych gdzieś $w$ jaskini $z$ dala od dawnych ośrodków cywilizacji. W świetle przytaczanych słów Rothbarda nie widać przeciwwskazań, dlaczego mieliby oni nie przyjąć modelu komunistycznego.

I w tym punkcie jednak wywód Rothbarda można $z$ sukcesem skorygować. Otóż nawet gdyby społeczeństwo składało się $z$ dwóch osób, to i tak aby zawrzeć porozumienie co do dopuszczalnych sposobów działania, musieliby oni wpierw dysponować prawem tego, by zadać pytanie i spróbować osiagnać zgodę $z$ druga strona. Tymczasem ponieważ brak działania także jest działaniem, w ramach "modelu komunistycznego" rozbitkowie $z$ naszego przykładu nie mogliby ani sformułować problemu, ani go nie sformułować, zachowując milczenie i stojąc niczym słupy soli. Ponownie zatem należy stwierdzić, że komunistyczna alternatywa $z$ dowodu Rothbarda wymaga niemożliwego.

Gerard Casey słusznie z kolei wskazuje na wage innego fragmentu argumentacji Rothbarda. „Jest absurdem twierdzić, że żaden człowiek nie ma prawa do posiadania siebie i równocześnie uważać, że każdy z ludzi ma prawo posiadać część wszystkich pozostałych!"67 - to w tej tezie należy upatrywać klucza do ostatecznego odrzucenia „modelu komunistycznego" jako dopuszczalnej z perspektywy prawa naturalnego formuły dystrybucji praw własności. Jak wskazuje Łukasz Dominiak, własne ciało stanowi jedyne dobro ekonomiczne, nad którym podmiot sprawuje kontrolę

67 Ibidem, s. 128-129. Zob. G. Casey. Feser on Rothbard..., op. cit.., s. 9. 
bezpośrednią. Nad wszelkimi innymi zasobami - w tym ciałami innych ludzi może on rozpościerać władztwo wyłącznie za pośrednictwem własnego ciała. ${ }^{68}$ Częściowe prawo własności $\mathrm{w}$ odniesieniu do pozostałych osób nie mogłoby zatem być egzekwowane bez absolutnego prawa własności do swojego ciała. Własność oznacza bowiem prawo do suwerennej kontroli nad tym, co stanowi jej przedmiot. Jest logicznie nie do pomyślenia, by A mógł być właścicielem czegokolwiek, nie będąc zarazem właścicielem siebie samego, to jest mając za właściciela kogoś innego. Rothbardowski model „komunistyczny” upada więc w końcu jako wewnętrznie sprzeczny.

W ogólnym planie etyki prawnonaturalnej zmienia to jednak niewiele. Ponieważ, jak wykazaliśmy, Rothbard bezpodstawnie odrzuca wariant, w którym jedna klasa ludzi jest własnościa drugiej, argument $a$ contrario za absolutnym prawem auto-własności okazuje się w podanym przez niego sformułowaniu nietrafny. Nadto, Rothbardowski argument nie pozwala udzielić odpowiedzi na pytanie bardziej pierwotne niż kwestia tego, jaki rozdział praw własności uznać można za sprawiedliwy. Zanim rozważy się rozmaite alternatywy jako słuszne bądź nie, trzeba wszak uwiarygodnić twierdzenie, że problem został właściwie postawiony, innymi słowy - że pytanie o słuszność ma sens. Zwolennicy nonkognitywistycznych stanowisk w metaetyce mogliby zupełnie nie zwracać uwagi na argumenty Rothbarda, zadowalając się konstatacją, że sądom normatywnym jako takim nie przysługuje wartość logiczna ${ }^{69}$. Rothbard expressis

${ }^{68}$ Ł. Dominiak, Aksjomatyczność zasady autowłasności..., op. cit.. s. 49/

${ }^{69}$ Gdyby mieli oni rację, adekwatny byłby wariant Mavrodesa: nikt nie posiadałby na własność niczego w wymiarze bardziej fundamentalnym niż ten zwiazany $z$ prawem pozytywnym. verbis ich pogląd odrzuca, zajmujac pozycje prawnonaturalnego kognitywizmu, wszelako racje stojące za iusnaturalizmem nie wydaja przekonujące, co po części uzasadniliśmy wyżej. Do wyłuszczonych dotąd racji dodać należy postawiony przez Hume'a i od jego czasów należący do najgoręcej dyskutowanych tematów filozofii moralności problem dualizmu faktów i norm. Autor „Etyki wolności”, idąc za przykładem przywoływanych przez siebie współczesnych rzeczników prawa naturalnego, próbuje, jak widzieliśmy, unieważnić tę dychotomię, ujmując normy jako zawarte $\mathrm{w}$ bycie - nie tyle $\mathrm{w}$ faktach (w terminologii arystotelesowsko-tomistycznej: aktach), co w potencji - tendencje-cele. Niestety dla niego: nie widać, jak ta linia obrony miałaby chronić iusnaturalizm przed tradycyjnymi zastrzeżeniami krytyków. Celowość to dystynktywna właściwość istot świadomych - bytów dla siebie (jak powiedziałby Jean-Paul Sartre) czy też działających ludzi (według Ludwiga von Misesa, lidera austriackiej szkoły ekonomii i mentora Rothbarda). Byty nieświadome (w języku Sartre'a: byty w sobie) maja natomiast taki cel, jaki wyznaczy im projektant bądź użytkownik. Jak w kontekście tzw. teleologicznego dowodu na istnienie Boga trafnie stwierdza Leszek Kołakowski:

Można w rzeczy samej utrzymywać, że celowość jest raczej nałożona na organiczną naturę, niż w niej spostrzegana. Jeśli utrzymujemy, że spostrzegamy w danym przedmiocie cel, to zakładamy już tym samym świadome autorstwo (...) A tymczasem w badaniu empirycznym celowości można zawsze zaprzeczyć, chyba że dotyczy ono wytworów, o których już wcześniej wiadomo, że są ludzkiego autorstwa"70.

${ }^{70}$ L. Kołakowski, Jeśli Boga nie ma... O Bogu. 
W agnostycznym światopoglądzie Rothbarda teleologiczna metafizyka nie może się utrzymać, toteż etykieta „tomisty bez teologii", przypięta Rothbardowi przez Petera McClelanda, jest doprawdy niszcząca. ${ }^{71}$ Skoro Boga nie ma lub przynajmniej nic nie wiadomo o jego istnieniu, to skad idea, by naturę postrzegać jako celową?

Użycie klucza jako narzędzia zbrodni nie jest dla niego mniej naturalne niż skorzystanie zeń celem otwarcia drzwi, bo też natura rzeczy to nic innego, jak zbiór jej dyspozycji (potencji). Skoro historia ludzkości to w dużej mierze dzieje wyzysku, przemocy, rabunku, mordów, opodatkowania, wojny, regulacji i etatyzmu - słowem, wszystkiego, czego libertariańska etyka zakazuje - to najwyraźniej leży to w naturze człowieka, tj. człowiek wykazuje swoja dyspozycję do tego, by rzeczy tak właśnie się miały. Oczywiście agresywne i destrukcyjne skłonności człowieka współegzystują $z$ tendencjami do pokoju i współpracy, jednakowoż na podstawie samego istnienia obydwu tych ludzkich oblicz niepodobna któremukolwiek $z$ nich przyznać etycznego priorytetu. Jak w znanym passusie pisał Immanuel Kant: „Z drewna tak krzywego jak to, z którego zrobiony jest człowiek, nie można wystrugać nic prostego". ${ }^{72}$

W szczególności nie można $z$ pojęcia natury ludzkiej wystrugać niczego, co można by określić jako aksjomat. Jak wspomniano, w literaturze libertariańskiej zasada nieagresji, stanowiaca

Diable, grzechu i innych zmartwieniach tzw. filozofii religii, tłum. T. Baszniak i M. Panufnik. Kraków 2010, s. 58.

71 P.D. McClelland, The American Search for Economic Justice, Oxford 1990, s. 74. Cyt. za: H-H. Hoppe, Przedmowa do wydania amerykańskiego, [w:] M.N. Rothbard, Etyka wolności. op. cit., s. 37.

${ }^{72}$ I. Kant, Idea powszechnej historii $w$ aspekcie kosmopolitycznym, [w:] Rozprawy z filozofii historii, tłum. T. Kupś i in., Kęty 2005, s. 36. logiczną równoważność praw własności i autowłasności, bywa czasem nazywana „aksjomatem”, innym razem zaś po prostu „zasadą". Niekonsekwencją w tym zakresie wykazywał się już - co dostrzega Feser - Rothbard, w „Manifeście libertariańskim” oraz „Sprawiedliwości i prawach własności” pisząc o „aksjomacie”, natomiast w najpóźniejszej „Etyce wolności" nie używając tego terminu. ${ }^{73}$ Wbrew polemizujacemu $z$ Feserem Caseyowi, który broni postrzegania zasady nieagresji jako aksjomatu, należy raczej przyjąć, że Rothbard - świadomie bądź nie, w każdym razie słusznie - wycofał się $z$ tej interpretacji. Cała jego argumentacja jest bowiem silnie osadzona $\mathrm{w}$ teorii prawa naturalnego, co oznacza, że jest założeniowa - nie stanowi, inaczej niż aksjomat sensu proprio, pierwotnego twierdzenia w ciagu przesłanek. ${ }^{74}$ Dotyczy to także argumentu nie wprost, który - znów wbrew Caseyowi - nie może, co wyraźnie widać $z$ naszych wywodów, zostać uznany ani za bezzałożeniowy, ani za dowód niemożliwości w rozumieniu Arystotelesa. ${ }^{75}$ Stagiryta, jak wiadomo, postrzegał jako aksjomat takie twierdzenie, które - jak choćby zasada (nie)sprzeczności - nie może być dowiedzione bez błędnego koła, lecz którego jednocześnie niepodobna odeprzeć, nie przyznając mu zarazem prawdziwości. ${ }^{76}$ Dowodowi Rothbarda niczego takiego przypisać nie sposób.

73 E. Feser. Rothbard as a Philosopher, op. cit.; idem, Rothbard Revisited, op. cit.

74 Jak wspominaliśmy, Feser domaga się, by Rothbard odniósł się także do pominiętej w swoim wykazie alternatywy dla auto-własności - posiadania wszystkich ludzi na własność przez Boga. Opcja ta zwyczajnie nie mieści się jednak w agnostycznym światopoglądzie Rothbarda. Problemem nie jest więc to, że Rothbard jej nie rozpatruje, lecz założeniowość jego etyki, niemożliwa do uzgodnienia $z$ postulatem jej aksjomatyczności. E. Feser, Rothbard as a Philosopher.

75 G. Casey, Feser on Rothbard..., op. cit., s. 3 i nn.

76 Arystoteles, Metafizyka, tłum. K. Leśniak, Warszawa 2009, 1006A 11-28. 


\section{Podsumowanie}

Konkludując, ambitny projekt filozoficzny Murraya Rothbarda, którego zamierzeniem było przedłożenie systemu racjonalnej etyki ufundowanej na pryncypiach libertarianizmu, okazuje się porażka wskutek osadzenia go na fundamencie teorii prawa naturalnego. Nie wynika stąd w żadnym wypadku, że libertarianizmu nie można ugruntować inaczej. Przeciwnie: piszacy te słowa sympatyzuje $z$ libertariańska filozofia polityczna i leżącymi u jej podstaw normami etycznymi. Wychodzimy jednakże z założenia, że kluczową wartością w filozofii nie sa tezy, lecz argumenty - te pierwsze moga być podtrzymane o tyle tylko, o ile drugie w dostatecznym stopniu je wspierają. Podzielając pewne stanowisko, nie wolno zatem godzić się, by broniono go za pomoca fałszywych racji. Dzieło Rothbarda rozwiną w swoich pracach Hans-Hermann Hoppe, podnoszac własny, nieufundowany na prawie naturalnym i mocniejszy od propozycji mistrza dowód niemożliwości etyki innej niż libertariańska, ${ }^{77}$ co Rothbard przyją $z$ dużym entuzjazmem, przyznając nawet, że na tle argumentów Hoppego jego „stanowisko prawnonaturalne wygląda mizernie". ${ }^{78}$ Mimo to w tym samym artykule deklarował, że nie dostrzega sprzeczności między swoim podejściem a koncepcja Hoppego i podtrzymał auto-

77 Etyka argumentacyjna Hoppego, bo o niej mowa, inspirowane jest przede wszystkim filozofia Immanuela Kant, Jürgena Habermasa i Karla-Otto Apla. Szerzej na jej temat piszemy w: N. Slenzok, Od transcendentalnej pragmatyki języka do libertariańskiej etyki argumentacyjnej, „Eryda” 1(3)/2016, s. 59-82. Zob. oryginalny wywód Hoppego: H-H. Hoppe, Ekonomia i etyka własności prywatnej, tłum. K. Nowacki, Warszawa 2011, s. 317-433; idem, Teoria socjalizmu $i$ kapitalizmu, thum. P. Nowakowski, Warszawa 2015, s. 129-147.

78 M. Rothbard, Beyond Is and Ough, „Liberty" 2/1988, s. 44. identyfikację jako teoretyka praw naturalnych. ${ }^{79}$

Nie ma tu miejsca na referat etyki ucznia Rothbarda, a tym samym na rozstrzygnięcie, czy i ewentualnie w jakim stopniu ich teorematy daja się ze soba - jak chciał Rothbard - uzgodnić. Dość jednak powiedzieć, że na innym fundamencie filozoficznym do obrony nadawałby się Rothbardowski dowód a contrario. Jak widzieliśmy, w ujęciu twórcy libertarianizmu był on nieprzekonywający nie dlatego, że - jak przekonuje Feser - podana przez Rothbarda lista alternatyw dla zasady autowłasności jest niewyczerpujaca. Dowód Rothbarda upada, gdyż na skutek ograniczeń teorii jusnaturalizmu boryka się $z$ problemem dualizmu faktów i norm, jak również brakuje mu uprawomocnienia standardu uniwersalizacji i co za tym idzie - podstaw do odrzucenia wariantu posiadania jednej klasy ludzi na własność przez druga. Hoppe, w swoich pracach mocno naciskajacy na respektowanie kryterium uniwersalizacji, lecz inaczej je fundujacy, nie bez powodu posługuje się niekiedy argumentem a contrario Rothbarda jako uzupełnieniem własnych koncepcji. ${ }^{80}$

My natomiast wykazaliśmy, że żaden $z$ dwóch argumentów podnoszonych przez Rothbarda nie może ostać się, dopóki funkcjonuje na gruncie teorii prawa naturalnego, a to $z$ co najmniej trzech zasadniczych powodów. Po pierwsze, $z$ uwagi na immanentne trudności towarzyszace idei prawa naturalnego per se. Po drugie, ze względu na niekompatybilność tej idei z liberalizmem i libertarianizmem. Po trzecie, co wolno potraktować

${ }^{79}$ Ibidem, s. 45.

${ }^{80} \mathrm{H}-\mathrm{H}$. Hoppe, Etyka i ekonomia własności prywatnej, op. cit., s. 22-23. Także we wstępie do Rothbarda etyki wolności Hoppe uznaje ten argument za „ostateczny”. H-H. Hoppe, Wstep do wydania amerykańskiego, op. cit., s. 16-17. 
jako egzemplifikację punktu drugiego, $z$ libertarianizmem nie współgra witalizm etyki Rothbarda. Wreszcie, nawet gdyby wszystkie inne obiekcje chybiały celu, koncepcja autora „O nową wolność" nie mogłaby uchodzić za aksjomatyczna, albowiem nie spełniałaby wymogu bezzałożeniowości.

\section{Bibliografia}

Arystoteles, Metafizyka, tłum. K. Lesniak, Warszawa 2009.

Barczentewicz Mikołaj, Etyka wolności Murraya Rothbarda, [w:] Rothbard Murray Newton, Etyka wolności, tłum. J. Wozinski, Warszawa 2010.

Berlin Isaiah, Pokrzywione drzewo człowieczeństwa, tłum. M. Tański, Warszawa 2004.

Camus Albert, Dwa eseje, tłum. J. Guze, Warszawa 1991.

Casey Gerard, Feser on Rothbard as a Philosopher, „Libertarian Papers” 1/34 (2009).

Dominiak Łukasz, Problem aksjomatyczności zasady autowłasności $w$ filozofii politycznej libertarianizmu, „Athenaeum. Polskie Studia Politologiczne” 49/2016.

Elzenberg Henryk. Kłopot $z$ istnieniem: aforyzmy $w$ porzadku czasu , Toruń 2002.

Feser Edward, Rothbard as a Philopher, dostęp z dn. 20.04.2017:http:/ / edwardfeser.blogspot.com/2009/08/rothbard-as-philosopher.html.

Feser Edward, Rothbard Revisited, dostęp z dn. 20.04.2017: http://edwardfeser.blogspot.com/2009/08/rothbard-revisited.html.
Gordon David, The Essential Rothbard, Aurburn 2007.

Gray John, Dwie twarze liberalizmu, tłum. P. Rymarczyk, Warszawa 2001.

Gray John, Po liberalizmie. Eseje wybrane, tłum. P. Maciejko i P. Rymarczyk, Warszawa 2001.

Hoppe Hans-Hermann. Ekonomia $i$ etyka własności prywatnej, tłum. K. Nowacki, Warszawa 2011.

Hoppe Hans-Hermann, Krótka historia człowieka. Libertariańska rekonstrukcja postępu i upadku, tłum. Ł. Dominiak, Warszawa 2014.

Hoppe Hans-Hermann, Przedmowa do wydania amerykańskiego, [w:] Rothbard Murray Newton, Etyka wolności, tłum. J. Wozinski, Warszawa 2010.

Hoppe Hans-Hermann, Teoria socjalizmu i kapitalizmu, tłum. P. Nowakowski, Warszawa 2015.

Hoppe Hans-Hermann, Wielka fikcja, państwo $w$ epoce schyłku, tłum. K. Nowacki, Warszawa 2014.

Huemer Michael, The Problem of Political Authority. An Examination of The Right to Coerse and the Duty to Obey, Basingtoke 2013.

Juruś Dariusz, W poszukiwaniu podstaw libertarianizmu. $W$ perspektywie Rothbardowskiej koncepcji własności, Kraków 2012.

Kant Immanuel, Rozprawy z filozofii historii, tłum. T. Kupś i in., Kęty 2005.

Kołakowski Leszek, Jeśli Boga nie ma... O Bogu. Diable, grzechu i innych zmartwieniach tzw. filozofii religii, tłum. T. Baszniak i M. Panufnik. Kraków 2010. 
Legutko Ryszard, Traktat o wolności, Gdańsk 2007.

Mises Ludwig von, Epistemological Problems of Economics, Aurburn 2003.

Mises Ludwig von, Ludzkie działanie. Traktat o ekonomii, przeł. W. Falkowski, Warszawa 2011.

Raimondo Justin, Przeciw państwu. Biografia MurrayaN. Rothbarda, thum. J. Wozinski, Warszawa 2016.

Rand Ayn, Cnota egoizmu: nowa koncepcja egoizmu, tłum. J. Łoziński, Poznań 2000.

Rothbard Murray Newton, Beyond Is and Ough, „Liberty” 2/ 1988.

Rothbard Murray Newton, Economic Thought Before Adam Smith. An Austrian Perspective on the History of Economic Thought vol. 1, Aurburn 1995.

Rothbard Murray Newton, Egalitaryzm jako bunt przeciwko ludzkiej naturze, tłum. K. Węgrzecki, Warszawa 2009.

Rothbard Murray Newton, Ekonomia wolnego rynku, t. 1 , tlum. R. Rudowski, Warszawa 2007.

Rothbard Murray Newton, Etyka wolności, tłum. J. Wozinski, Warszawa 2010.
Rothbard Murray Newton, O nowa wolność. Manifest libertariański, tłum. W. Falkowski, Warszawa 2007.

Slenzok Norbert, Idea wolności $w$ etyce społecznej Murraya N. Rothbarda, [w:] Sroczyński Olgierd (red.), Wolność, moralność $i$ efektywność. Wybrane problemy współczesnej etyki społecznej $i$ gospodarczej, Katowice 2014.

Slenzok Norbert, Od transcendentalnej pragmatyki języka do libertariańskiej etyki argumentacyjnej, „Eryda” 1(3)/2016.

Strauss Leo, Prawo naturalne $w$ świetle historii tłum. T. Górski, Warszawa 1969.

Tokarczyk Roman, Klasycy praw natury, Lublin 1988.

Weber Max, Gospodarka i społeczeństwo. Zarys socjologii rozumiejacej, tłum. tłum. D. Lachowska, Warszawa 2002.

Wielomski Adam, Konserwatyzm. Główne nurty, idee i postacie, Warszawa 2006.

Wojtyszyn Radosław, Anty-Lewiatan. Doktryna polityczna $i$ prawna Murraya Newtona Rothbarda, Wrocław 2017.

Wozinski Jakub, Antropologia libertarianizmu, Poznań 2016. 